\title{
Effect of Certain Quinones on Adenosine Triphosphate Level in Human Bladder Cancer Cells
}

\author{
H. ZHU1 AND H. WANG*
}

State Key Laboratory of Environmental Chemistry and Ecotoxicology, Research Center for Eco-Environmental Sciences, Chinese Academy of Sciences, Beijing 100085, ${ }^{1}$ University of Chinese Academy of Sciences, Beijing 100049, China

\section{Zhu and Wang: Effect of Quinones ATP Level in Human Bladder Cancer Cells}

\begin{abstract}
The aim of this study was to reveal the relationship between four kinds of quinones and the ATP level in human bladder cancer T24 cells. Quinones could cause damage to T24 cells, and after 12 h exposure, IC $_{50}$ values were in $\mu \mathrm{M}, 74$ for 2-chlorobenzoquinone, 82 for 2,5-dichloro-1,4-benzoquinone, 122 for 2,6-dichloro-1,4-benzoquinone and 45 for 2,3,6-trichloro-1,4-benzoquinone. Further, the mechanism of increased ATP level when exposed to the 4 quinones was studied. It could be due to increased reactive oxygen species level in T24 cells when exposed to these quinones, which suppressed the ATPase activity, leading to increased levels of ATP, which was dose-dependent. The higher the quinone concentration was, the higher the reactive oxygen species level and the ATPase activity was lower, leading to accumulation of more ATP in T24 cells. This study indicated that these 4 quinones could block energy metabolism in T24 cells which could lead to cell death.
\end{abstract}

Key words: Quinones, ATP, T24

Quinones are widely found in natural products, antitumor drugs, biochemical metabolites and environmental pollutants. Recently, these have been found in drinking water and other foods ${ }^{[1-5]}$. It has been reported that some quinones can produce large amounts of unknown disinfection by products, which were poorly evaluated for toxicity ${ }^{[6-8]}$. There have been reports that certain kinds of quinones can cause damage to cells, such as the ectogenic quinones derived from the metabolism of the body, which could induce a series of toxic effects, including acute cytotoxicity ${ }^{[9-12]}$, immunotoxicity and carcinogenicity ${ }^{[13-16]}$. It is reported that quinones are highly reactive oxidation products, which can produce reactive oxygen species (ROS), and in turn, cause damage to cells and bodies. As generally known, ATP is the main sources of energy supplement in cells ${ }^{[17-20]}$, which is an important substance to support life and either absence of or excess ATP level in cells cause damage. There have been reports that ATP level can be affected by many processes. In the present investigation it was observed that the 4 quinones tested enhanced ATP levels in T24 cells. The reason could be that these quinones can decrease ATPase activity in T24 cells dose-dependently. This observation indicated that these 4 quinones could block energy production, which could provide a way to kill T24 cells.

\section{MATERIALS AND METHODS}

Standards of the ATP, disodium hydrogen phosphate $\left(\mathrm{Na}_{2} \mathrm{HPO}_{4} \cdot 12 \mathrm{H}_{2} \mathrm{O}\right)$, 2-chlorobenzoquinone (CBQ), 2,5-dichloro-1,4-benzoquinone

2,6-dichloro-1,4-benzoquinone (2,5-DCBQ), (2,6-DCBQ) and ATPase activity assay kit were procured from SigmaAldrich, USA. Methanol from Thermo Fisher Scientific, USA and acetic acid from Sinopharm Chemical Reagent Beijing Co., Ltd. China. DMEM-high glucose culture medium was procured from Lonza, Walkersville, MD USA, 2,3,6-trichloro-1,4-benzoquinone (TCBQ, Acros Organic, USA), ROS assay kit (Beyotime Biotechnology, China), DNA damage competitive Elisa kit (Invitrogen, USA), OxiSelect MDA adduct kit (Cell Biolabs, USA), CellTiter 96® aqueous one solution cell proliferation assay kit (Promega, USA), pyruvate kinase assay kit (Abcam, England), mitochondrial membrane potential (MMP) assay kit (Beyotime Biotechnology, China), were used in present study. Shimadzu HPLC system (LC-20A, Japan), Microplate reader (Varioskan Flash, Thermo Scientific, USA), 
microplate spectrometer (ACEA NovoCyte, China), Confocal laser scanning microscope (TCS SP5, Leica, Germany) were also used.

\section{Cell and sample preparation:}

T24 cells were cultured in DMEM-high glucose medium with $100 \mu \mathrm{g} / \mu \mathrm{l}$ streptomycin, $10 \% \mathrm{FBS}$, $100 \mathrm{U} / \mathrm{ml}$ penicillin, $5 \% \mathrm{CO}_{2}$ at $37^{\circ}$. The cell number was calculated using a haemocytometer and washed twice by pre-cooled phosphate buffer saline (PBS). Lysis was done by $100 \mu 180 \%$ pre-cooled methanol $(\mathrm{v} / \mathrm{v})$, then centrifuged at $12000 \mathrm{rpm}\left(4^{\circ}\right)$ for $10 \mathrm{~min}$. The supernatant was placed in an ultrafiltration device and centrifuged for $30 \mathrm{~min}$ at $13500 \mathrm{rpm}$ (at $4^{\circ}$ ), finally, $80 \mu \mathrm{l}$ mobile phase $\mathrm{A}\left(50 \mathrm{mM} \mathrm{Na} \mathrm{HPO}_{4}, 15 \mathrm{mM}\right.$ trimethylamine (TEA), $\mathrm{pH} 7.88$ using acetic acid) was added to the $80 \mu$ f filtered solution.

\section{Determination of ATP Level:}

ATP level was quantified using HPLC. Angela Venusil MP C18 column $(250 \times 4.6 \mathrm{~mm}$ i.d., particle size $5 \mu \mathrm{m}$ ) was used. Mobile phase A was $50 \mathrm{mM}$ disodium hydrogen phosphate and $15 \mathrm{mM}$ TEA, $\mathrm{pH}$ was adjusted to 7.88 with acetic acid, mobile phase B was $100 \%$ methanol. Isocratic elution, $4 \%$ methanol and flow rate of $0.8 \mathrm{ml} / \mathrm{min}$ were used. The injection volume was $20 \mu \mathrm{l}$. The peaks of various ingredients were recorded at $254 \mathrm{~nm}$.

\section{Cell viability:}

Cell viability was calculated using MTS assay. Cell viability data was based on the manufacturer's instructions with little modification. T24 cells were cultured at 96-well plates (15 000 cells/well). After incubated for $24 \mathrm{~h}$, the culture media in samples, blank and negative controls was replaced by the media, which various concentrations of HBQs $(0,10,20,50,100,150$, $200,300 \mu \mathrm{M})$ was contained. Each concentration was sextupled. After exposed for $12 \mathrm{~h}$, each well was pipet $20 \mu \mathrm{l}$ CellTiter $96 \AA$ aqueous one solution, and incubated for $1 \mathrm{~h}$ in an incubator which contained $5 \% \mathrm{CO}_{2}$. The result was recorded by a microplate spectrometer at $490 \mathrm{~nm}$. Based on the cell viability curves, $\mathrm{IC}_{50}$ values of the 4 hydroxybenzoquinones (HBQs) were determined. $\mathrm{IC}_{50}$ value was the concentration of HBQs required to reduce $\mathrm{T} 24$ cells to $50 \%$.

\section{ROS level in T24 cells:}

ROS level was quantified by ROS assay kit with some modifications. Ten-cm plates were used, the density was 107 cells/well and cultured for $24 \mathrm{~h}$ before the following tests. Briefly, 7'-dichlorofluorescin diacetate
(DCFH-DA) was diluted 1000 folds in the culture medium, which is free of serum medium, and the final concentration was $10 \mu \mathrm{M}$, the culture medium was removed and added $2.5 \mathrm{ml}$ the above diluted DCFHDA to each plates, incubated at $37^{\circ}$ for $25 \mathrm{~min}$, washed 3 times with serum-free culture medium and finally suspended in $1 \mathrm{ml}$ PBS. ROS was determined in a flowcytometer.

\section{Detection of 8-hydroxy-2'-deoxyguanosine (8-OHdG):}

8-OHdG level in T24 cells was determined by DNA damage competitive ELISA kit with some modifications. Twenty five microlitres of $8-\mathrm{OHdG}$ standard was added to a tube which contained $475 \mu$ lassay buffer. Then, added appropriate assay buffer to 8 tubes. The concentrations were 4000, 2000, 1000, 500, 250, 125, 62.6 and $0 \mathrm{pg} / \mathrm{ml}$ standard solution of 8-OHdG. Added $50 \mu \mathrm{l}$ of standards or samples to appropriate wells. Then, assay buffer $(75 \mu \mathrm{l})$ was added to each well, next, $25 \mu \mathrm{l}$ of 8-OHdG conjugate and $25 \mu 18-\mathrm{OHdG}$ antibody, the plates were mixed well and incubated for $2 \mathrm{~h}$ at room temperature. Then, $100 \mu \mathrm{l}$ TMB substrate was added and incubated for another $30 \mathrm{~min}$, and last, added $50 \mu 1$ stop solution, mixed well and read the absorbance at $450 \mathrm{~nm}$.

\section{Detection of MDA Adducts:}

All reagents were mixed thoroughly before using. Each MDA sample was assayed two times. Added $50 \mu \mathrm{l}$ of samples or MDA-BSA standards to the MDA conjugate coated plate, then added $50 \mu \mathrm{l}$ of the diluted antiMDA antibody. Finally, incubated in ambient temperature for $1 \mathrm{~h}$. Washed each well by $250 \mu \mathrm{l}$ of wash buffer for 3 times. Incubated for another $1 \mathrm{~h}$ after $100 \mu \mathrm{l}$ diluted antibody-HRP conjugate was added. Washed the wells for 3 times by the wash buffer, and next add $100 \mu$ of substrate solution, then, added $100 \mu 1$ of stop solution. Finally, the absorbance of each well was read at $450 \mathrm{~nm}$ by a microplate reader.

\section{Determination of MMP:}

MMP was quantified by the MMP assay kit with some modifications. The cells were cultured in 4-well plates, the culture medium was removed after being exposed to quinones for $12 \mathrm{~h}$, and washed with the PBS buffer. Then, $200 \mu \mathrm{l}$ staining solution was added to each well and cultured in a cell incubator for $20 \mathrm{~min}$. Next, washed the cells by $200 \mu \mathrm{l}$ fresh and pre-warmed JC-1 buffer for 2 times, finally, $200 \mu \mathrm{l}$ culture medium was added to the wells. Spectral characteristics were determined 
by Leica TCS SP5 system. The excitation wavelength was $490 \mathrm{~nm}$, and the emission wavelength was $530 \mathrm{~nm}$.

\section{Detection of pyruvate kinase activity:}

Cells were extracted with 4 volumes of assay buffer, centrifuged at $12000 \mathrm{rpm}$ for $5 \mathrm{~min}$ to get clear extract. Added $10 \mu 1$ samples directly into a 96-well plate, made up to $50 \mu \mathrm{l}$ per well with PK assay buffer, diluted the pyruvate standard to generate $0,2,4,6,8$ and $10 \mathrm{nmol}$ per well, $50 \mu 1$ reaction mix was added to each well and measured the $\mathrm{OD}_{570 \mathrm{~nm}}$ at $\mathrm{T}_{1}$ to get $\mathrm{A}_{1}, \mathrm{~A}_{2}$ was read after incubating for $15 \mathrm{~min}\left(\mathrm{~T}_{2}\right)$. Plot the pyruvate standard curve, $\mathrm{B}$ nmol of pyruvate generated between $\mathrm{T}_{1}$ and $\mathrm{T}_{2}$ by the standard curve. $\mathrm{PK}$ activity $=(\mathrm{B} \times$ sample dilution factor $) /\left(\left(\mathrm{T}_{2}-\mathrm{T}_{1}\right) \times \mathrm{V}\right)=\mathrm{nmol} / \mathrm{min} / \mathrm{ml}$.

\section{Detection of ATP synthase activity:}

Fifty microliters of diluted sample was added into a 96-well pre-coated microplate, incubated for $3 \mathrm{~h}$ at ambient temperature. The enzyme was immobilized in the wells with the monoclonal antibody. Then, the well contents were emptied and $300 \mu \mathrm{l}$ of solution 1 was added to each well. Emptied the wells again, then, $300 \mu \mathrm{l}$ solution 1 was added to each well. Emptied the wells again and $40 \mu \mathrm{l}$ of lipid mix was added and incubated at room temperature for $45 \mathrm{~min}$. Finally, $200 \mu \mathrm{l}$ reagent mix was added. Any bubbles in the wells should be popped and the absorbance of each well was measured at $340 \mathrm{~nm}$.

\section{Detection of ATPase activity:}

Added $0,10,20,25,30$, and $40 \mu$ of the $50 \mu \mathrm{M}$ standard solution to 96-well plate, generating $0,12.5,25,31.25$, 37.5 and $50 \mu \mathrm{M}$ standards solution, then, ultrapure water was added to each well to bring the volume to $40 \mu \mathrm{l}$. T24 cells were homogenized on ice with $200 \mu 1$ pre-cooled assay buffer. Centrifuged for $5 \mathrm{~min}$ (14 $000 \mathrm{rpm}), 10 \mu \mathrm{l}$ of the above supernatants was added to 96 -well plate. Negative control was $10 \mu \mathrm{l}$ of assay buffer, then $30 \mu \mathrm{l}$ reaction mix was added, incubated for $30 \mathrm{~min}, 200 \mu \mathrm{l}$ stop solution was added, incubated for another $30 \mathrm{~min}$. $\mathrm{OD}_{620 \mathrm{~nm}}$ was read by microplate reader. ATPase enzyme activity $=$ (concentration of phosphate $(\mu \mathrm{M}) \times$ reaction volume $(\mu \mathrm{l})) /($ sample volume $(\mu \mathrm{l}) \times$ reaction time $(\mathrm{min}))=\mu \mathrm{mol} / \mathrm{min} / 1$.

\section{RESULTS AND DISCUSSIONS}

ATP was the main energy source in cells, it maintained the cells function well, and involved in almost all the cellular processes. So, ATP level could serve as an indicator of cytotoxicity of various biological compounds on cells. In this study, ATP level was quantified by the developed method previously and the results in fig. 1 showed that the 4 quinones had dosedependent positive effects on ATP level in T24 cells. The hypothesis proposed was that ATP decomposed or generated pathway might be influenced by the 4 quinones. The detailed explanation was as follows.

T24 cells at various concentrations for $12 \mathrm{~h}$ were determined by developed HPLC method. The green colored column represented cells treated with 2-CBQ (left to right). The blue colored column represents cells treated with 2,5-DCBQ (left to right). The purple colored column represented T24 cells treated with 2,6-DCBQ (left to right). The red colored column represented T24 cells treated with various concentrations of TCBQ (left to right).

MTS was used to determine the T24 cell viability. Data in fig. 2 showed cell viability after incubated with varying concentrations of 2-CBQ, 2,5-DCBQ, TCBQ and 2,6-DCBQ. A significantly reduced viability could be observed when treated with the 4 HBQs.

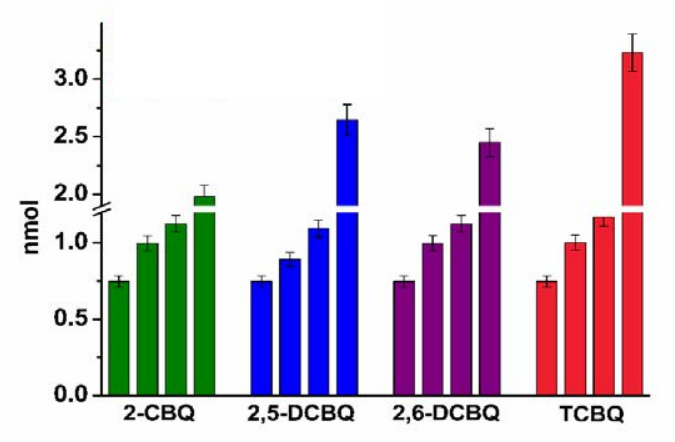

Fig. 1: Effect of the 4 BHQs on ATP level

(匹) 2-CBQ (0, 10, 20, $40 \mu \mathrm{M})$, (匹) 2,5-DCBQ (0, 10, 20, $40 \mu \mathrm{M})$, (घ) 2,6-DCBQ (0, 10, 20, $40 \mu \mathrm{M})$, (घ) TCBQ $(0,10,20,40 \mu M)$. ATP levels are per 106 cells

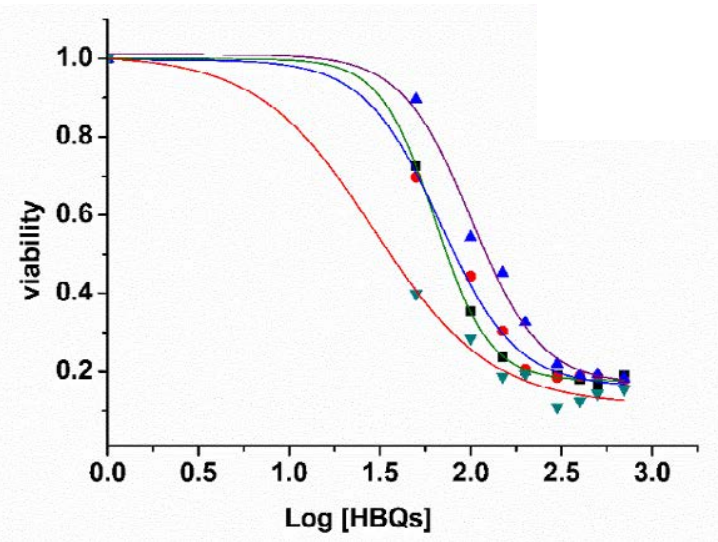

Fig. 2: Effects of the $4 \mathrm{HBQs}$ on the viability

The $\mathrm{IC}_{50}$ values were $74 \mu \mathrm{M}$ for 2 -CBQ $(-), 82 \mu \mathrm{M}$ for 2,5 DCBQ (-), $122 \mu \mathrm{M}$ for 2,6-DCBQ (-) and $45 \mu \mathrm{M}$ for TCBQ (一). Six replicates were incubated 
The $\mathrm{IC}_{50}$ values were $74 \mu \mathrm{M}$ for $2-\mathrm{CBQ}, 82 \mu \mathrm{M}$ for 2,5-DCBQ, $122 \mu \mathrm{M}$ for 2,6-DCBQ, and $45 \mu \mathrm{M}$ for TCBQ. Differential cytotoxicity of the 4 HBQs on T24 cells could be observed; TCBQ had the lowest $\mathrm{IC}_{50}$, which indicated that the TCBQ had the highest cytotoxic effect. To ensure the cell viability was higher than $50 \%, 10,20$ and $40 \mu \mathrm{M}$ was chosen for the following tests.

The overall ROS level in T24 cells was determined when induced by the four HBQs. After exposed to various concentrations of the $4 \mathrm{HBQs}(0-40 \mu \mathrm{M})$ for $12 \mathrm{~h}$, the ROS level was measured using a ROS kit. The statistics in fig. $3 \mathrm{~A}$ indicated that the 4 quinones exerted dose-dependent positive effect on the intracellular ROS production. As known, ROS impacts many signal transduction pathways including respiratory

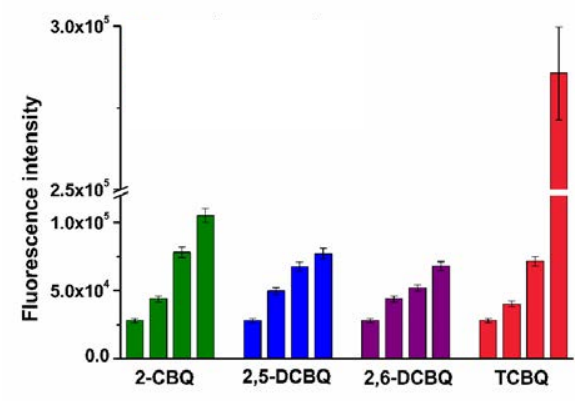

A

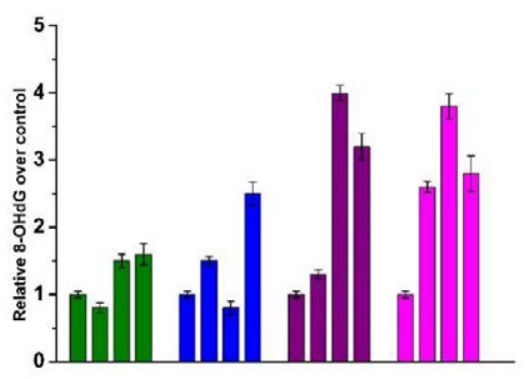

B

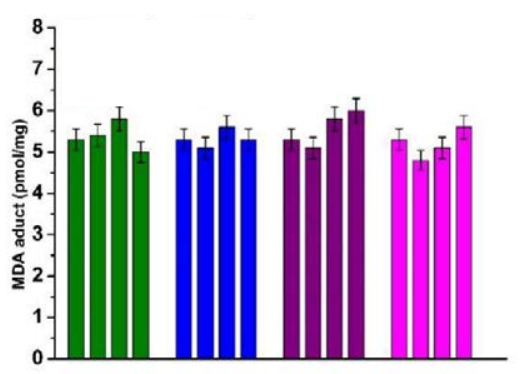

C

Fig. 3: Effects of the four kinds of HBQs on the viability. Six replicates were incubated

(घ) 2-CBQ $(0,10,20,40 \mu \mathrm{M}),( \pm)$ 2,5-DCBQ $(0,10,20,40 \mu \mathrm{M})$, (घ) 2,6-DCBQ (0, 10, 20, $40 \mu \mathrm{M})$, (घ) TCBQ $(0,10,20,40 \mu \mathrm{M})$ chain, which was the main pathway that consume the intracellular ATP. The increased ROS level might be related to the increased ATP level.

8-OHdG was an important indicator of oxidative damage, which led to DNA damage. Fig. 3B showed that 8 -OHdG level increased in T24 cells treated with different quinones. It was not dose-dependent. Therefore, the results indicated that the generated 8-OHdG was compound-dependent.

Lipid peroxidation could indicate oxidative stress in cells. The increase of MDA level might lead to cytotoxicity or cell death. The results in fig. 3C indicated that MDA protein adducts in cells changed little when treated with quinones. These results in this study suggested that lipids were not the target of HBQ.

In mammalian cells, mitochondria are the major sources of intracellular ATP. This study explored whether the observed increased intracellular ATP level correlated to the MMP. It was estimated that the MMP of quinoneexposed T24 cells by staining cells with JC-1. T24 cells were exposed to 10,20 and $40 \mu \mathrm{M}$ quinones for $12 \mathrm{~h}$ and incubated with JC-1 for $20 \mathrm{~min}$. The MMP was estimated by confocal microscopy, as the fluorescence intensity of JC-1 correlates with the intracellular MMP level. As shown in fig. 4, cells showed no significant change between the exposed and the control groups in fluorescence intensity, which suggested that the four HBQs had no effect on intracellular MMP, and caused no damage to the mitochondrial.

Pyruvate kinase was an intracellular glycolysis process enzyme. It could cause great change in cells, so it was an important pathway to generate ATP in cells. This study quantified the pyruvate kinase activity in T24 cells by pyruvate kinase kit. Data in fig. 5A indicated that the pyruvate kinase activity kept constant with increasing HBQ concentration. It suggested that the four HBQs had no effect on the PK activity, and the observed increasing of ATP was not caused by the changes of PK activity.

The ATP synthase complex, which was also called complex $\mathrm{V}$ or $\mathrm{F}_{1} \mathrm{~F}_{0}$-ATPase, was responsible for ATP production in the oxidative phosphorylation process. It was the key enzyme for the production of ATP in cells, so, ATP synthase activity level was measured before and after exposure to the 4 quinones using the ATP synthase activity kit. The data in fig. 5B indicated that ATP synthase activity had no significant change between the control and the quinone-treated groups, and it meant that there was no relationship between the 
increased ATP level and the activity of ATP synthase in T24 cells.

ATPases catalyse the decomposition of ATP into ADP and free phosphate. Thus, intracellular ATPase activity played key role in maintaining ATP level in cells. ATPase activity was measured using ATPase activity assay kit. The results in fig. $5 \mathrm{C}$ indicated that the ATPase activity dose-dependently decreased when exposed to the four HBQs, thus allowing to speculate that the observed increased ATP level in T24 cells might be a result of decreased ATPase activity.

The above results indicated that the ROS level caused by the four quinones might be the main reason responsible for the increased ATP level when exposed to quinones. The mechanism scheme was presented in the graphic abstract.

It was reported that the effects of four quinones on ATP level in T24 cells and the key effector of it. Dosedependent increase in ATP levels could be observed in the T24 cells exposed to quinones for $12 \mathrm{~h}$. The reason for this phenomenon was investigated (fig. 6). It was observed that increased ATP level might be caused by the following reasons, the ROS level in T24 cells increased after exposure to the HBQs, the high level of ROS might have reduced ATPase activity, and as a result, the ATP levels were elevated. The higher the HBQ concentration was, the higher the ROS levels, resulting in lowered ATPase activity and reduced decomposition and accumulation of ATP in T24 cells. This study indicated that the energy generating pathway

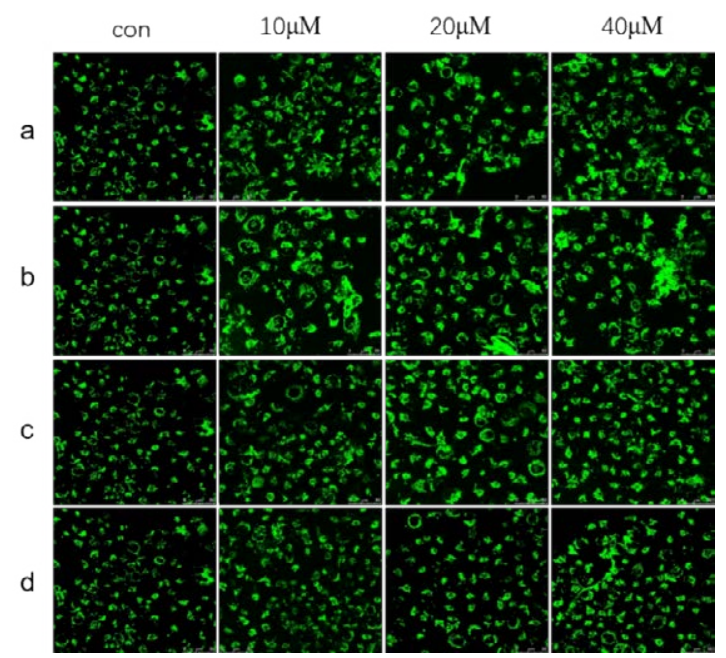

Fig. 4: Effect of the 4 BHQs on mitochondrial membrane potential

T24 cells at various concentrations for $12 \mathrm{~h}$ were determined by confocal microscopy with JC-1 staining. Con represent control groups. (a) T24 cells treated by $2-\mathrm{CBQ}$, (b) cells treated by 2,5DCBQ, (c) T24 cells treated by 2,6-DCBQ, (d) T24 cells treated by TCBQ

Special Issue 2, 2020

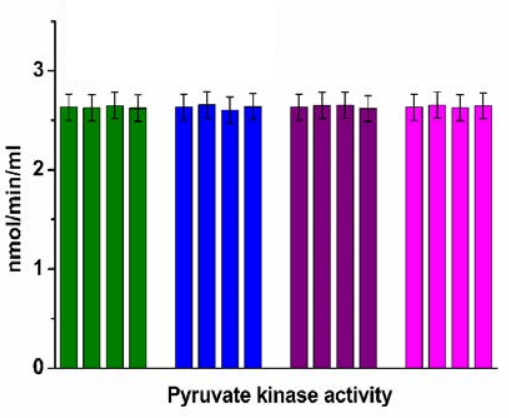

A

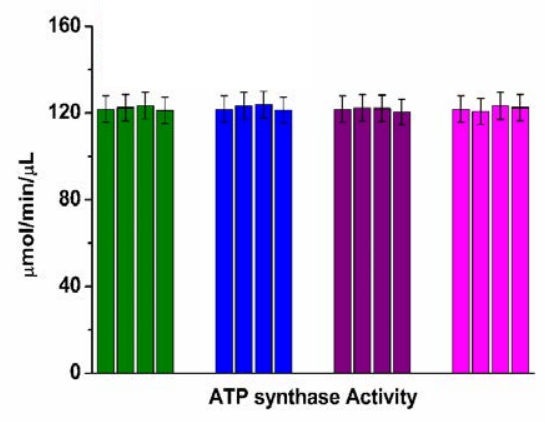

B

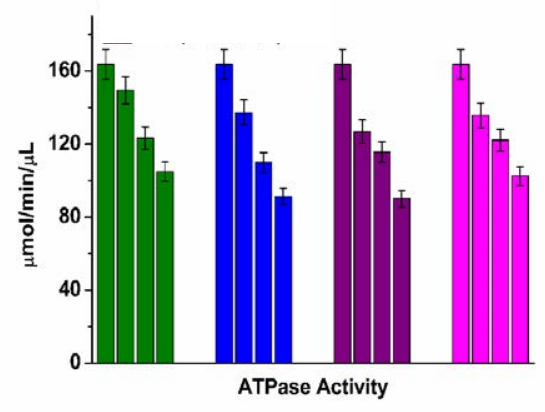

C

Fig. 5: Effect of the 4 BHQs on (A) Pyruvate kinase activity, (B) ATP synthase activity, and (C) ATPase activity (匹) 2-CBQ (0, 10, 20, $40 \mu \mathrm{M})$, (घ) 2,5-DCBQ (0, 10, 20, $40 \mu \mathrm{M})$, (匹) 2,6-DCBQ (0, 10, 20, $40 \mu \mathrm{M})$, (

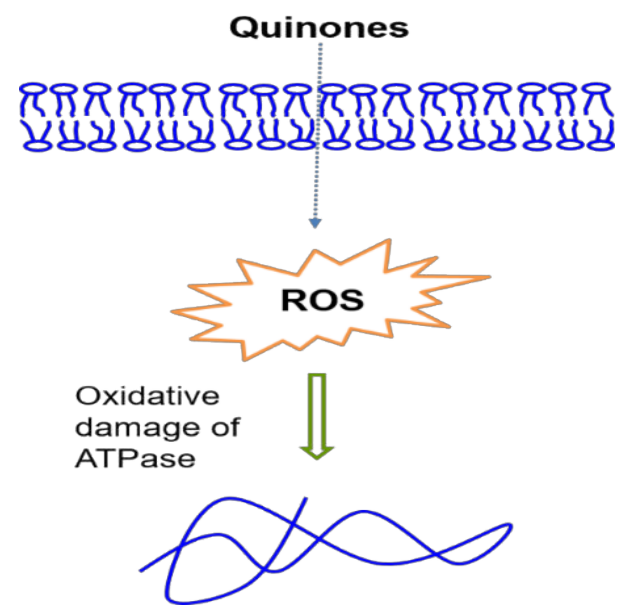

Fig. 6: Mechanism 
might be blocked by the 4 quinones, resulting in cell death.

\section{REFERENCES}

1. Pillar EA, Guzman MI. Oxidation of Substituted Catechols at the Air-Water Interface: Production of Carboxylic Acids, Quinones, and Polyphenols. Environ Sci Technol 2017;51(9):4951-9.

2. Yang P, Zeng Q, Cao WC. Interactions between CYP2E1, GSTZ1 and GSTT1 polymorphisms and exposure to drinking water trihalomethanes and their association with semen quality. Environ Res 2016;147:445-52.

3. Richardson SD, Plewa MJ, Wagner ED, Schoeny R, Demarini DM. Occurrence, genotoxicity, and carcinogenicity of regulated and emerging disinfection by-products in drinking water: A review and roadmap for research. Mutat Res 2007;636(3):178-242.

4. Alegria AE, Ferrer A, Sepulveda E. Photochemistry of watersoluble quinones. Production of a water-derived spin adduct. Photochem Photobiol 1997;66(4):436-42.

5. Murzakaev VG, Latypova ZV. Experimental study of the hazards and safety levels in water of chlorinated quinones. Gig Sanit 1972;37(5):15-19.

6. Cantor KP, Villanueva CM, Silverman DT. Polymorphisms in GSTT1, GSTZ1, and CYP2E1, disinfection by-products, and risk of bladder cancer in Spain. Environ Health Perspect 2010;118(11):1545-50.

7. Hua G, Reckhow DA. Comparison of disinfection byproduct formation from chlorine and alternative disinfectants. Water Res 2007;41(8):1667-78.

8. Krasner SW, Weinberg HS, Richardson SD. Occurrence of a new generation of disinfection byproducts. Environ Sci Technol 2006;40(23):7175-85.

9. Kuete V, Omosa LK, Tala VRS. Cytotoxicity of Plumbagin, Rapanone and 12 other naturally occurring Quinones from Kenyan Flora towards human carcinoma cells. BMC Pharmacol Toxicol 2016;17(1):60-9.

10. Abiko Y, Puga A, Kumagai Y. Covalent binding of quinones activates the Ah receptor in Hepalc1c7 cells. J Toxicol Sci 2015;40(6):873-86.

11. Nishiyama T, Hatae N, Yoshimura T. Concise synthesis of carbazole-1,4-quinones and evaluation of their antiproliferative activity against HCT-116 and HL-60 cells. Eur J of Med Chem 2016;121:561-77.
12. Shang Y, Zhang L, Jiang Y. Airborne quinones induce cytotoxicity and DNA damage in human lung epithelial A549 cells: the role of reactive oxygen species. Chemosphere 2014;100(3):42-9.

13. Verrax J, Beck R, Dejeans N. Redox-active quinones and ascorbate: an innovative cancer therapy that exploits the vulnerability of cancer cells to oxidative stress. Anticancer Agents Med Chem 2011;11(2):213-21.

14. Sheng K, Lu J. Typical airborne quinones modulate oxidative stress and cytokine expression in lung epithelial A549 cells. J Environ Sci Health A Tox Hazard Subst Environ Eng 2016;52(2):127-34.

15. Ja DLM, Lawson JC, Chiwakata MT. Quinones and halogenated monoterpenes of algal origin show antiproliferative effects against breast cancer cells in vitro. Invest New Drugs 2012;30(6):2187-200.

16. Slamenová D, Masterová I, Lábaj J. Cytotoxic and DNAdamaging effects of diterpenoid quinones from the roots of Salvia officinalis L. on colonic and hepatic human cells cultured in vitro. Basic Clin Pharmacol Toxicol 2004;94(6):282-90.

17. Aho J, Helenius M, Vattulainen-Collanus S. Extracellular ATP protects endothelial cells against DNA damage. Purinergic Signal 2016;12(3):575-81.

18. Dartier J, Lemaitre E, Chourpa I. ATP-dependent activity and mitochondrial localization of drug efflux pumps in doxorubicin-resistant breast cancer cells. Biochim Biophys Acta Gen Subj 2017;1861(5):1075-84.

19. Li X, Fang P, Yang WY. Mitochondrial ROS, uncoupled from ATP synthesis, determine endothelial. Can J Physiol Pharmacol 2016;95(3):1-6.

20. Maldonado EN, Dehart DN, Patnaik J. ATP/ADP Turnover and Import of Glycolytic ATP into Mitochondria in Cancer Cells is Independent of the Adenine Nucleotide Translocator. J Biol Chem 2016;291(37):19642-50.

This is an open access article distributed under the terms of the Creative Commons Attribution-NonCommercial-ShareAlike 3.0 License, which allows others to remix, tweak, and build upon the work non-commercially, as long as the author is credited and the new creations are licensed under the identical terms

This article was originally published in a special issue:
Special issue on "Drug Development and Human Health in
China"
Indian J Pharm Sci $2020: 82(1)$ spl issue2;1-6

